\title{
THE ANALYSIS OF THE PUNCTURE STRENGTH OF NONWOVEN GEOTEXTILE MATERIALS MADE FROM POLYESTER AND POLYPROPYLENE FIBRES
}

Dragan Đorđićí, Jovan Stepanovićz ${ }^{2}$ Dušan Trajković ${ }^{2}$

1 Cis Institute, Belgrade, Serbia

2 Faculty Of Technology, University of Niš, Leskovac, Serbia

A very important characteristic of geosynthetic materials, besides the breaking force and deformation, is the puncture strength of geotextiles. Considering that the purpose of installation geosynthetic materials and inter alia to stabilize and strengthen the soil in which they are installed, it is necessary that they have a high puncture strength in order to fulfill its function. Geotextile materials suffer a great burden and at the installation process, in contact with smaller and larger sharp rocks, and if they have poor puncture resistance they may be damaged. In addition to stabilizing the soil in which they are installed, geotextile materials are used for the protection of geomembranes from puncturing or as an obstacle to sharp materials that are used in a construction to damage geomembrane. For this purpose it is necessary to withstand a lot of pressure on their surface, and to prevent the contact of the sharp material with the geomembrane. This paper presents the analyzed samples of nonwoven geotextile materials made from regular polyester, recycled polyester and polypropylene fibers. Based on the obtained values, it is possible to create an image of the values of the forces that these materials can be submitted to, as well as the differences between geotextiles produced from regular and recycled polyester and polypropylene.
(PROFESSIONAL PAPER)

UDC 677.494:677.076.4:624.138.2
Keywords: puncture strength, geotextile, polyester, polypropylene

\section{Introduction}

The use of geosynthetic in construction proved to be the solution that saves money and significantly improves the properties of the building in relation to classical techniques of the construction of certain types of objects, as well as soil stabilization and the road construction. The installation of geotextiles is performed under difficult conditions and the damage to geotextile comes in its installation so, after the installation in the soil, it must have a big resistance to damage i.e. it must keep all their properties (separation, filtration, drainage, stabilization, protection). It was also found that a significant influence on the resistance to penetration of geotextiles (CBR) has a density of the surface material and the material thickness. The parameters that influence the effectiveness of the protective function of sharp parts are the thickness of the geotextile which is laid, its surface mass and its resistance to penetration at large pressure forces.

There are two commonly used types penetration tests for geotextile, a dynamic test (puncturing with coneCone drop test) and a static puncture test (puncturing with steel piston-CBR). According to the manual for the design of roads in Serbia in 2012 [1], for the accepted class material for installation, geosynthetic -in addition to the value of breaking force, accompanying stretching and energy absorption, a geotextile material mustmeet the criteria in terms of resistance to static and / or dynamic puncturing. The puncture resistance must be determined by the procedure of a dynamic penetration test (Cone drop test) according to the SRPS EN ISO 13433:2009 [2].

The diameter of Od openings which make a cone in geotextile can be:

- for the installation material A: Od $<35 \mathrm{~mm}$,

- for the installation material B: Od $<30 \mathrm{~mm}$,

- for the installation material C: Od $<25 \mathrm{~mm}$ [1].

This test involves the measuring of the effect of the mass of the cone which fell on geotextiles.

This test allows the comparative classification of different products, but there is no quantified measuring of their strength [3].

With this test, it is possible to estimate the mechanical resistance of geotextiles to the impacts of stone aggregates during the phase of filling the position. The standard prescribed for this type of testing [2] defines the steel cone weighing $1000 \mathrm{~g}$ falling vertical to the sample of geotextile from the height of $500 \mathrm{~mm}$, fixed between the two rings with the inner diameter of $150 \mathrm{~mm}$. At the end of the testing, the diameter of the hole in geotextiles samples is measured by using a graduated steel cone (Figure 1).

\footnotetext{
*Author address: Dragan Đorđić, CiS Institute,

Vojislava llića 88, 11000 Belgrade, Serbia

E-mail: ddjordjic@yahoo.com

The manuscript received: May, 09, 2016.

Paper accepted: June, 14, 2016.
} 


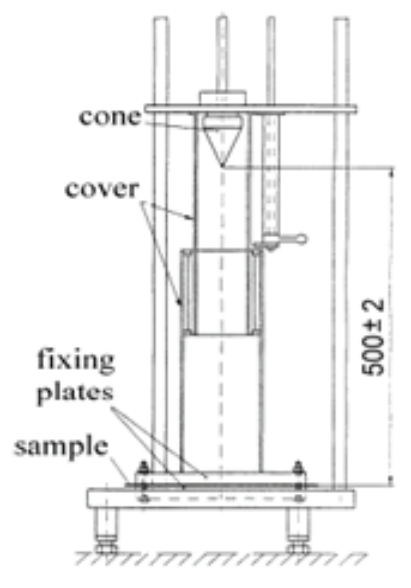

a)

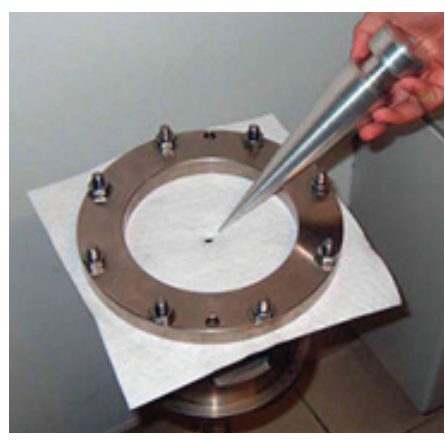

b)
Figure 1. Schematic of the apparatus for dynamic punching [4] (a) and the appearance of the sample after puncturing (b)

The smaller the diameter of the hole after puncturing, the greater is the resistance of geotextile on the damage. For the determination of the resistance to penetration, the static test penetration with steel piston (CBR) according SRPS EN ISO 12236:2012 can alternatively be used.

Minimum force required for a breakthrough, can be:

- for the installation material A: Fp > 1500N

- for the installation material B: $F p>2000 \mathrm{~N}$

- for the installation material C: $F p>2500 N$ [1].

The puncturing test (CBR) simulates the pressure of large pieces of stone and aggregates that are imprinted into the geotextile which is laid on a soft sub-base. This method is standardized worldwide and it determines the resistance to geotextile puncture by penetrating the steel cylinder with a diameter of $50 \mathrm{~mm}$ through the $150 \mathrm{~mm}$ sample diameter, until the value of the force of penetration in Newtons is determined. The known values of CBR test can help in predicting the behavior of geotextiles on endurance under the concentrated load and its slow punching.

Selecting the right penetration test depends mainly on the structure of the material to be used during the installation, so it is necessary to choose the appropriate test suitable for determining the penetration force to simulate the behavior of geotextile during the installation. Each test has its own value for a specific situation. CBR penetration test provides an indication of capacity and durability of geotextiles at slow puncturing. It allows the selection of one geotextile with sufficient robustness to minimize the damage and to ensure proper installation characteristics required during the life of the product [4] The value of the penetration force is greatly influenced by manufacturing parameters such as the density of the material surface and the thickness of the material [5].

\section{Experimental}

The tested geotextile materials are manufactured under industrial conditions from regular PES fiber, then from recycled PES fibers and PP fibers (Table 1). Produced geotextile materials have surface mass cca. 150 $\mathrm{gm}^{-2}$, cca. $200 \mathrm{gm}^{-2}$, cca. $250 \mathrm{gm}^{-2}$, cca. $300 \mathrm{gm}^{-2}$ and cca. $500 \mathrm{gm}^{-2}$.

Table 1. Characteristics of PES A, PES B and PP fibers used for the production of geotextiles

\begin{tabular}{llllllll}
\hline $\begin{array}{l}\text { Type of } \\
\text { fibers }\end{array}$ & $\begin{array}{l}\text { The average } \\
\text { length of } \\
\text { fibers, } \mathrm{L} f_{f} \\
{[\mathrm{~mm}]}\end{array}$ & $\begin{array}{l}\text { Fiber } \\
\text { fineness, } \\
\mathrm{Tt}_{\mathrm{f}} \\
{[\mathrm{dtex}]}\end{array}$ & $\begin{array}{l}\text { Relative } \\
\text { breaking } \\
\text { force of } \\
\text { fiber, } \mathrm{F}_{\mathrm{r}} \\
{\left[\mathrm{cN} \cdot \mathrm{tex}^{-1}\right]}\end{array}$ & $\begin{array}{l}\mathrm{CV} \\
{[\%]}\end{array}$ & $\begin{array}{l}\text { Breaking } \\
\text { elongation, }\end{array}$ & $\begin{array}{l}\mathrm{CV} \\
{[\%]}\end{array}$ & $\begin{array}{l}\text { Melting } \\
\text { point } \\
\text { of fibers } \\
{\left[{ }^{\circ} \mathrm{C}\right]}\end{array}$ \\
\hline PES A & 62,0 & 6 & 44,3 & 8,9 & 32,7 & 22,0 & 245,34 \\
PES B & 83,1 & 6 & 37,7 & 19,4 & 63,5 & 24,8 & 242,11 \\
PP & 86,4 & 6 & 48,2 & 23,3 & 68,7 & 25,2 & 152,85 \\
\hline
\end{tabular}

For testing of geotextile materials (geotextile T-150, 200, 250, 300 and 500 PES A, PES B and PP) the following methods were used:

SRPS EN ISO 9864 : 2005- Geotextiles - Determination of the mass per unit area

SRPS EN ISO 12236: 2012 - Geosynthetic - Static puncture test (CBR test)

In examining the penetration force a steel piston diameter $50 \pm 0.5 \mathrm{~mm}$ (Fig. 2) was used.

Testing was conducted on five representative samples. After conditioning the samples and their preparation, the sample is fixed to a steel ring, the load is adjusted to the $20 \mathrm{~N}$ and the testing begins with a continuous lowering of the piston of $50 \pm 5 \mathrm{~mm}-\mathrm{min}^{-1}$ until it passes vertically through the sample, when a required force to puncture the test sample is recorded. The mean value of five test samples was shown. 


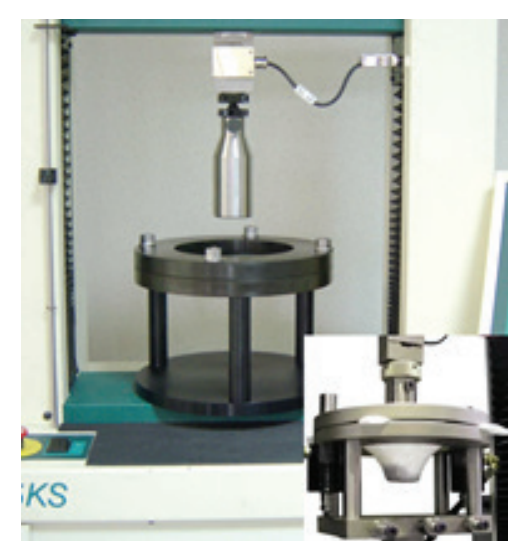

Figure 2. Static puncture-CBR test according to SRPS EN ISO 12236:2012

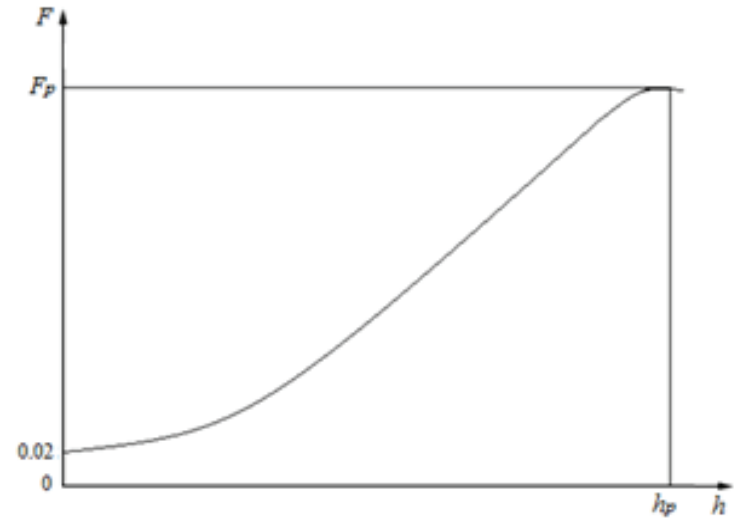

Figure 3. Example of a typical curve - Plunger force versus plunger displacement (SRPS EN ISO 12236:2012) [6]

Where is:

$h$ - displacement, in $\mathrm{mm}$

$F$ - plunger force, in $\mathrm{kN}$

$F p$ - push-through force, in $\mathrm{kN}$

$h p$ - push-through displacement, in $\mathrm{mm}$

Table 2. shows the parameters of a needling process and characteristics of geotextile materials.

\begin{tabular}{llllll}
\hline $\begin{array}{l}\text { Mark of geotextile } \\
\text { materials }\end{array}$ & $\begin{array}{l}\text { Type of } \\
\text { fiber for } \\
\text { production }\end{array}$ & $\begin{array}{l}\text { Needling } \\
\text { intensity } \\
{\left[\mathrm{min}^{-1}\right]}\end{array}$ & $\begin{array}{l}\text { Output speed } \\
{\left[\mathrm{m} \cdot \mathrm{min}^{-1}\right]}\end{array}$ & $\begin{array}{l}\text { Thickness at } \\
\mathrm{p=2 \textrm {KPa }} \\
{[\mathrm{mm}]}\end{array}$ & $\begin{array}{l}\text { Width } \\
{[\mathrm{cm}]}\end{array}$ \\
\hline Geotextile T-150 A & PES A & 750 & 2,4 & $1,5-1,9$ & 200 \\
Geotextile T-200 A & PES A & 750 & 2,0 & $1,6-2,25$ & 200 \\
Geotextile T-250 A & PES A & 750 & 1,9 & $2-2,7$ & 200 \\
Geotextile T-300 A & PES A & 750 & 1,75 & $2,4-3,2$ & 200 \\
Geotextile T-500 A & PES A & 750 & 1,0 & $2,8-3,6$ & 200 \\
Geotextile T-150 B & PES B & 750 & 2,4 & $1,4-1,8$ & 200 \\
Geotextile T-200 B & PES B & 750 & 2,0 & $1,6-2,1$ & 200 \\
Geotextile T-250 B & PES B & 750 & 1,9 & $2-2,5$ & 200 \\
Geotextile T-300 B & PES B & 750 & 1,75 & $2,2-2,8$ & 200 \\
Geotextile T-500 B & PES B & 750 & 1,0 & $2,2-2,9$ & 200 \\
Geotextile T-150 PP & PP & 750 & 2,4 & $1,7-2,3$ & 200 \\
Geotextile T-200 PP & PP & 750 & 2,0 & $1,9-2,4$ & 200 \\
Geotextile T-250 PP & PP & 750 & 1,9 & $1,9-2,5$ & 200 \\
Geotextile T-300 PP & PP & 750 & 1,75 & $2,2-3,0$ & 200 \\
Geotextile T-500 PP & PP & 750 & 1,0 & $3,1-3,9$ & 200 \\
\hline
\end{tabular}

Table 3. The results of the surface mass and the puncture force

\begin{tabular}{|c|c|c|c|c|c|c|c|c|c|c|c|c|c|c|c|}
\hline \multirow{3}{*}{$\begin{array}{l}\text { Geotextile } \\
\text { Surface mass } \\
\text { No.of samples }\end{array}$} & \multicolumn{6}{|c|}{ PES A } & \multirow{2}{*}{\multicolumn{3}{|c|}{$\begin{array}{l}\text { PES B } \\
150 \mathrm{gm}^{-2}\end{array}$}} & \multirow{2}{*}{\multicolumn{6}{|c|}{ PP }} \\
\hline & & & & & & & & & & & & & & & \\
\hline & 1 & 2 & 3 & 4 & 5 & 1 & 2 & 3 & 4 & 5 & 1 & 2 & 3 & 4 & 5 \\
\hline $\begin{array}{l}\text { Surface } \\
\operatorname{mass}\left(\mathrm{gm}^{-2}\right)\end{array}$ & 143 & 149 & 149 & 150 & 152 & 135 & 139 & 141 & 143,5 & 144 & 142 & 147 & 149 & 156 & 157 \\
\hline $\begin{array}{l}\text { Puncture force } \\
\text { CBR (N) }\end{array}$ & 694 & 650 & 637 & 710 & 850 & 435 & 450 & 377 & 420 & 410 & 1254 & 1490 & 1455 & 1384 & 1448 \\
\hline Surface mass & \multicolumn{15}{|c|}{$200 \mathrm{gm}^{-2}$} \\
\hline No.of samples & 1 & 2 & 3 & 4 & 5 & 1 & 2 & 3 & 4 & 5 & 1 & 2 & 3 & 4 & 5 \\
\hline $\begin{array}{l}\text { Surface } \\
\operatorname{mass}\left(\mathrm{gm}^{-2}\right)\end{array}$ & 184 & 188 & 190 & 204 & 211 & 203 & 204 & 207 & 215 & 220 & 192 & 193 & 200 & 209 & 211 \\
\hline $\begin{array}{l}\text { Puncture force } \\
\text { CBR }(N) \\
\text { Surface mass }\end{array}$ & 1089 & 1037 & 1014 & 1153 & 1161 & 598 & 637 & $\begin{array}{c}615 \\
250 \mathrm{gn}\end{array}$ & ${ }_{2}^{659}$ & 700 & 1452 & 1589 & 1751 & 1694 & 1805 \\
\hline No.of samples & 1 & 2 & 3 & 4 & 5 & 1 & 2 & 3 & 4 & 5 & 1 & 2 & 3 & 4 & 5 \\
\hline $\begin{array}{l}\text { Surface } \\
\operatorname{mass}\left(\mathrm{gm}^{-2}\right)\end{array}$ & 243 & 255 & 260,5 & 269 & 269 & 231 & 237 & 238 & 249 & 275 & 225 & 247 & 248 & 249 & 253 \\
\hline $\begin{array}{l}\text { Puncture force } \\
\text { CBR }(N) \\
\text { Surface mass }\end{array}$ & 1228 & 1384 & 1337 & 1487 & 1452 & 724 & 701 & $\begin{array}{c}758 \\
300 \mathrm{gn}\end{array}$ & $\begin{array}{r}780 \\
2\end{array}$ & 801 & 2107 & 2250 & 2204 & 2158 & 2209 \\
\hline No.of samples & 1 & 2 & 3 & 4 & 5 & 1 & 2 & 3 & 4 & 5 & 1 & 2 & 3 & 4 & 5 \\
\hline $\begin{array}{l}\text { Surface } \\
\operatorname{mass}\left(\mathrm{gm}^{-2}\right)\end{array}$ & 289 & 294 & 299 & 302 & 310 & 285 & 292 & 297 & 301 & 302 & 275 & 290 & 291 & 291 & 298 \\
\hline $\begin{array}{l}\text { Puncture force } \\
\text { CBR }(N)\end{array}$ & 1395 & 1357 & 1415 & 1508 & 1489 & 1108 & 1075 & 1150 & 1105 & 1227 & 2467 & 2624 & 2595 & 2744 & 3058 \\
\hline Surface mass & \multicolumn{15}{|c|}{$500 \mathrm{gm}^{-2}$} \\
\hline No.of samples & 1 & 2 & 3 & 4 & 5 & 1 & 2 & 3 & 4 & 5 & 1 & 2 & 3 & 4 & 5 \\
\hline $\begin{array}{l}\text { Surface } \\
\operatorname{mass}\left(\mathrm{gm}^{-2}\right)\end{array}$ & 494 & 500 & 514 & 529 & 536 & 454 & 464 & 466 & 471 & 499 & 484 & 493 & 506 & 522 & 527 \\
\hline $\begin{array}{l}\text { Puncture force } \\
\text { CBR (N) }\end{array}$ & 2791 & 2805 & 2820 & 2843 & 2850 & 2234 & 2241 & 2235 & 2301 & 2229 & 3907 & 4105 & 4082 & 4207 & 4250 \\
\hline
\end{tabular}




\section{Results and discussion}

Under the same production and technological conditions (Table 2), the results (Table 3 ) show that the nonwoven geotextile material from regular PES fiber has better resistance to static punching than the geotextile formed from recycled PES fibers. It has also been shown that the geotextile material from polypropylene fibers has better values than the geotextile made from regular polyester fibers. This difference indicates that the quality of PP fibers largely defines the quality of the geotextile material.

In Figures 4,5,6,7 and 8, comparative overviews of punching forces of geotextiles material from regular PES $A$, recycled PES B and PP fiber are shown.

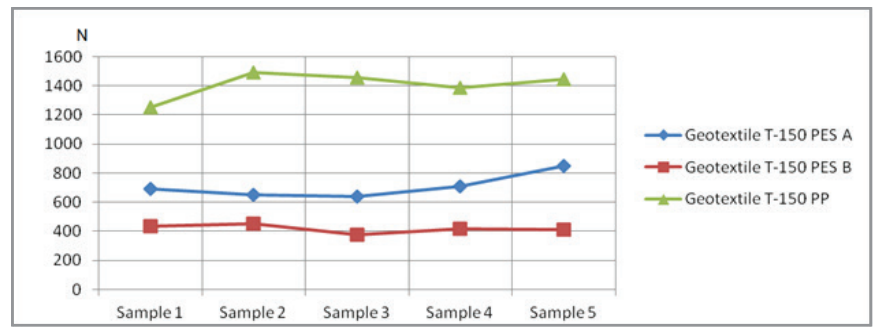

Figure 4. Comparative overview of the punching force of the geotextile of $150 \mathrm{gm}^{-2}$

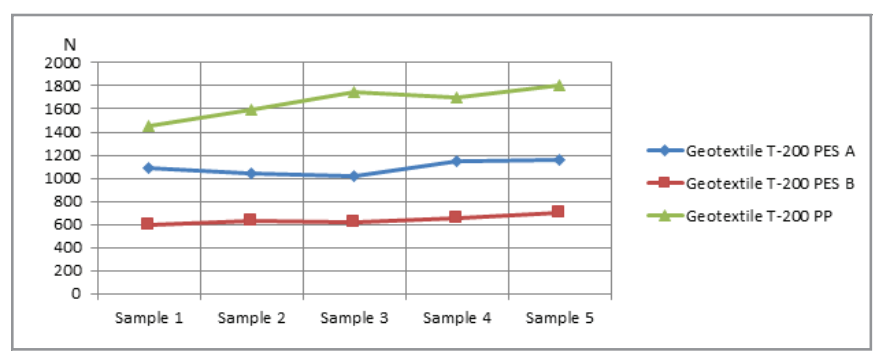

Figure 5. Comparative overview of the punching force of the geotextile of $200 \mathrm{gm}^{-2}$

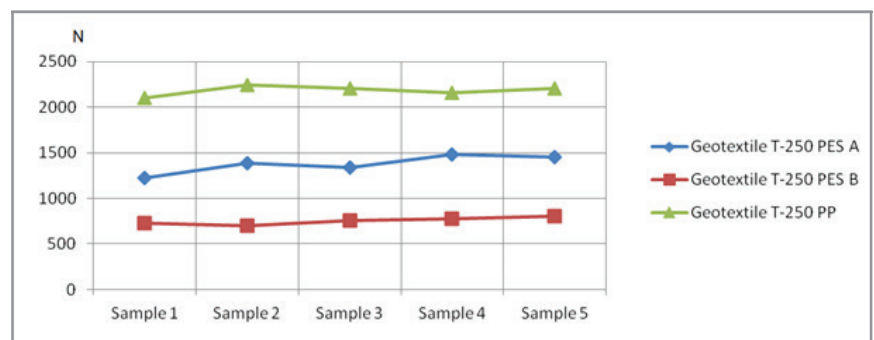

Figure 6. Comparative overview of the punching force of the geotextile of $250 \mathrm{gm}^{-2}$

It is evident that the geotextile of PP fibers shows the greatest resistance to penetration, while the lowest value recorded was for the geotextile manufactured from recycled polyester fibres. Certain values are up to three times greater for polypropylene geotextiles in relation to the recycled polyester. Geotextiles made from regular polyester fiber shows better values as compared to the recycled polyester but again significantly lower than for the geotextile made from polypropylene.

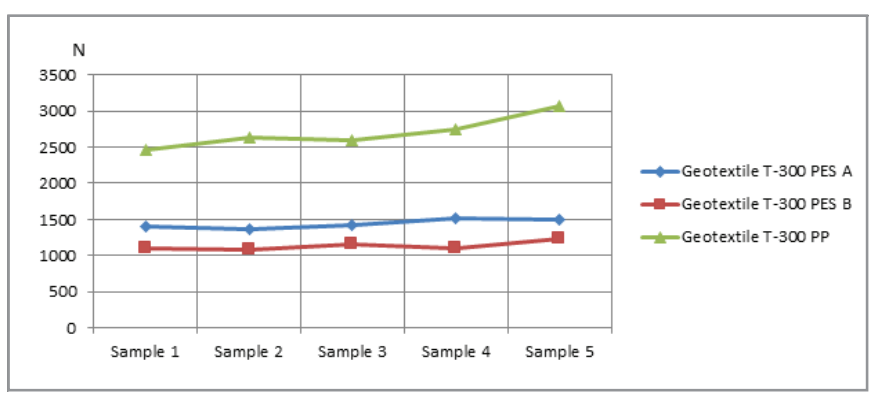

Figure 7. Comparative overview of the punching force of the geotextile of $300 \mathrm{gm}^{-2}$

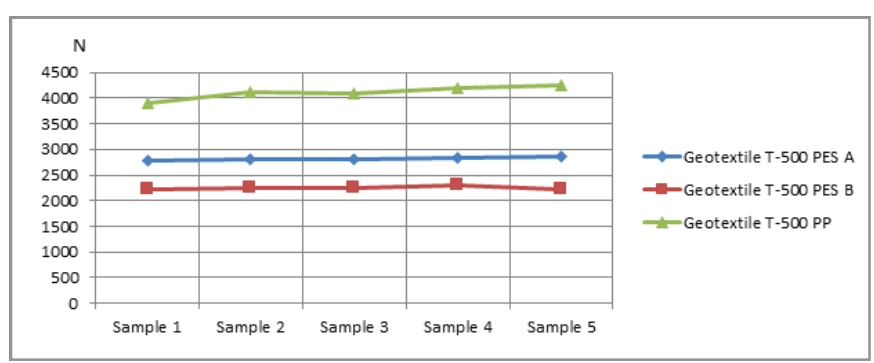

Figure 8. Comparative overview of the punching force of the geotextile of $500 \mathrm{gm}^{-2}$

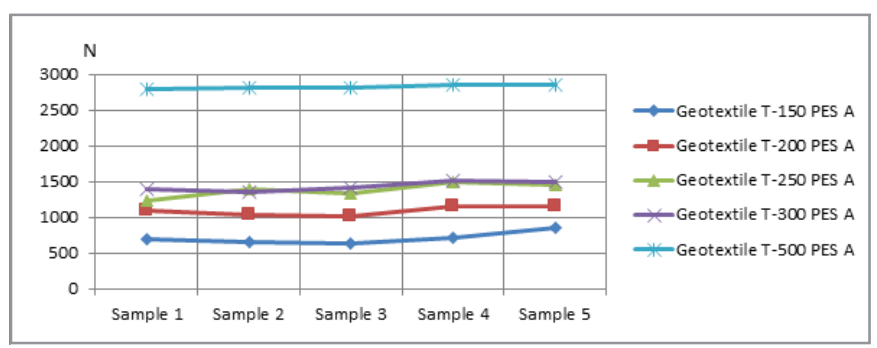

Figure 9. Comparative overview of the penetration force for all samples for PES A

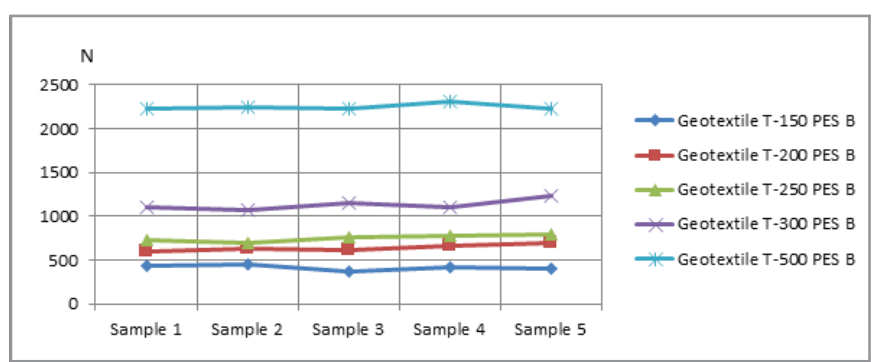

Figure 10. Comparative overview of the penetration force for all samples for PES B

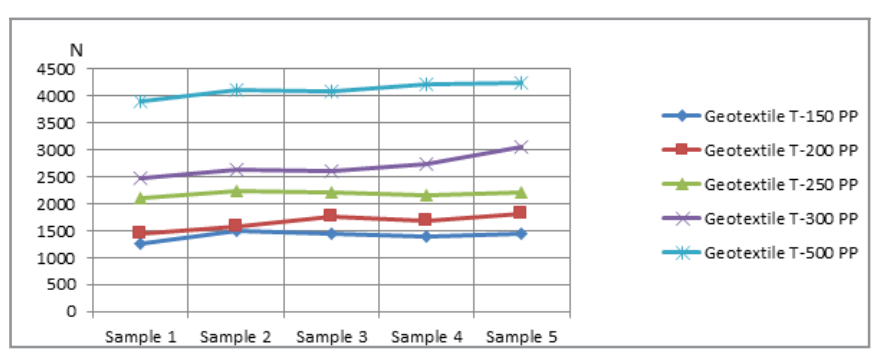

Figure 11. Comparative overview of the penetration force for all samples for PP 
In Figures from 9 to 11, comparative overviews of geotextile punching force for each fiber composition are presented, paying special attention to all surface masses from 150 to $500 \mathrm{gm}^{-2}$.

Looking at Figures from 9 to 11 it can be concluded that with the increase of the surface mass in all the samples there is simultaneously an increase of the puncture force.

The results of the analysis of the punching force needled nonwoven geotextiles can be used for the selection of geotextile in accordance with the future purposes.

\section{Conclusion}

From the comparison of the results presented in this paper, it is clear that when larger construction reinforcement and insurance from geotextile penetration is needed, the geotextile made of PP fibers is recommended. It is also evident that with the selection of high values of the surface mass, a greater resistance to the punching force of geotextiles can be expected. The presented results can be helpful when it comes to choosing a specific surface weight of geotextiles as they clearly show the degree of the progressive growth in the puncture strength with increasing the surface mass.

By possessing the data for the values of the puncture force of geotextiles of various material composition and surface mass, the possibility of making good decisions when choosing a geotextiles is achieved. A proper selection of a geotextile material for a particular purpose multiple increases the service life and the quality of the construction itself and significantly reduces the cost of maintaining the structure.

\section{References}

[1] Manual for the design of roads in the Republic of Serbia (SRDM8-1), Public Enterprise Serbian Roads, Transport Rehabilitation Project, Ground work, Belgrade 2012.

[2] SRPS EN ISO 13433:2009 - Geosynthetics -Dynamic perforation test (cone drop test)

[3] R. Antoine and L. Courard, Perforation strength of geosynthetics and sphericity of coarse grains: a new approach, Geotextiles and Geomembranes, Volume 14, Issue 10, 1996.

[4] A. Bolt, A. Duszynska, Static puncture resistance of non-woven geotextiles, The 10 th International Conference, Vilnius, Lithuania, (2010) 1083-1088.

[5] A. Rawal, S. Anand, T.Shah, Optimization of Parameters for the Production of needlepunched nonwoven Geotextiles, Journal of Industrial Textiles Vol. $37 n^{\circ} .4$, (2008) 341-356.

[6] SRPS EN ISO 12236:2012 - Geosynthetic - Static puncture test (CBR test)

Izvod

\section{ANALIZA SILA PROBIJANJA NETKANIH GEOTEKSTILNIH MATERIJALA OD POLIESTERSKIH I POLIPROPILENSKIH VLAKANA}

Dragan Đorđić1, Jovan Stepanović ${ }^{2}$ Dušan Trajković

\footnotetext{
1 Cis Institut, Beograd, Srbija

2 Tehnološki fakultet, Univerzitet u Nišu, Leskovac, Srbija
}

Izuzetno važna karakteristika geotekstilnih materijala pored prekidne sile i deformacije je i sila probijanja geotekstila. S obzirom da je svrha ugradnje geotekstilnih materijala između ostalog i da stabilizuju i ojačaju tlo u koje se ugrađuju neophodno je da imaju veliku silu probijanja kako bi ispunili svoju funkciju. Geotekstilni materijali trpe veliko opterećenje i pri samoj ugradnji, pri kontaktu sa agregatom i krupnijim oštrim kamenjem, i ukoliko imaju slabu otpornost na probijanje mogu biti oštećeni. Osim za stabilizaciju tla u koje se ugrađuju, geotekstilni materijali se koriste i za zaštitu geomembrana od probijanja, odnosno predstavljaju prepreku za oštre materijale koji se koriste u izgranji da oštete geomembranu a za tu svrhu je opet neophondno da mogu da podnesu veliki pritisak na svoju površinu i spreče kontakt oštrih materijala sa geomembranom. U radu su predstavljene vrednosti analiziranih uzoraka netkanog geotekstila od regularnih poliesterskih, recikliranih poliesterskih i polipropilenskih vlakana. Na osnovu dobijenih vrednosti moguće je stvoriti sliku o vrednostima sile koju ovi materijali mogu podneti kao i razlike između geotekstila proizvedenih od regularnog i recikliranog poliestra i polipropilena.
(STRUČNI RAD)

UDK 677.494:677.076.4:624.138.2

Ključne reči: sila probijanja, geotekstil, poliestar, polipropilen 